\title{
Who Performed at Newington Butts in May 1586? 1
}

\begin{abstract}
While recent studies offer new information about companies that used the Playhouse at Newington Butts from 1575 to 1594, mystery remains about the identity of the company that performed there in contravention of a restraint in May 1586. Using evidence related to the movements of companies active in 1586, particularly from the Records of Early English Drama (REED), this article offers an answer based on a process of elimination. After ruling out other options, the article explains why a fragment of Leicester's Men likely performed at Newington for a short time before joining the earl on his diplomatic campaign in Europe.
\end{abstract}

Contrary to popular belief, the paper trail related to the Playhouse at Newington Butts, ${ }^{2}$ a mile south of London, is relatively fulsome when it comes to identifying the companies it housed. While there is no body of documents that might help us compile a complete record of the venue's use from its initial operations ca 1575 through to its closure in 1594, in much the same way that entrepreneur Phillip Henslowe's ledger has furnished us with details of the operation of the Rose from 1592 onwards, a significant number of documents relevant to this question does exist. In almost all of the documents from which scholars have attempted to prove the existence of the Playhouse, to identify its location, or to comprehend the nature of its operations, information also exists regarding the companies whose performers graced its stage. One key exception is the pair of letters issued by the Privy Council on 11 May 1586, relating to the players who performed at Newington Butts in contravention of a ban. Neither letter mentions the identities, affiliations, or patron of these players, so scholars widely accept the impossibility of knowing who these players might have been. Such uncertainty will remain if scholars wait for the appearance of a document that explicitly names a player or company in association with Newington Butts in May 1586. My aim here is to demonstrate that the pathway to answering the question may lie not in the

Laurie Johnson (laurence.johnson@usq.edu.au) is a professor of English and cultural studies at the University of Southern Queensland. 
records related to Newington Butts but in the records related to everywhere else. Our picture of provincial visits by companies comes most directly from REED publications and the Patrons and Performances site, but in some respects also from Andrew Gurr (whose Shakespearian Playing Companies lists some performance dates based on records catalogued in Malone Society Collections but not yet in REED) and, before both of them, John Tucker Murray. ${ }^{3}$ By drawing on the playing companies' touring records, I argue that the only company of substance whose whereabouts cannot be ascertained with any certainty in May 1586 is the Earl of Leicester's Men, making them the most likely candidate for the players to whom the privy council letters were referring.

Jerome Savage converted the Playhouse at Newington Butts into a performance venue ca 1575 to provide the company of which he was a leading member, the Earl of Warwick's Players, with a relatively stable base near London, as the work of William Ingram has established. ${ }^{4}$ When the privy council ordered a restraint on 10 November 1578 against 'certen players within the Boroughe of Southwarke and other places nere adjoyning within that parte of Surreye, who by meanes of alluring of the people to their plays doe augement the infection of the Plages in London', 5 the certain players in question were surely Warwick's, still performing at Newington Butts. ${ }^{6}$ By 1580 , though, Savage had moved out of the Playhouse property, but the new leaseholder, Peter Hunningborne, was prepared, apparently, to make the venue available to playing companies right up until his lease expired. On 6 July 1594, the dean and chapter of Canterbury granted the lease to Paul Buck under the strict condition that he convert the Playhouse to some other use. ${ }^{7}$ On 13 May 1580, the privy council ordered the Surrey justices to stop players performing at the Playhouse in contravention of the ban issued on 17 April. ${ }^{8}$ Ingram argues that John and Laurence Dutton had by this time reconstituted Warwick's players under the earl of Oxford's patronage - if Ingram is right, then Oxford's Players would have been performing at Newington Butts at the time of the privy council order in 1580. ${ }^{9}$ Newington Butts is later identified in a trio of documents in the Dulwich College Library (a petition by the watermen to the lord admiral, a letter from Lord Strange's Men to the privy council, and the council's reply) as the venue that Strange's Men used for three days due to a closure of the Rose. The date of these documents remains a subject of debate; nevertheless, Strange's Men clearly did, at some point, perform at Newington Butts. ${ }^{10}$ Finally, courtesy of Phillip Henslowe's record of accounts, we know that for eleven days in June 1594 the Playhouse hosted performances by the Lord Admiral's Men and the Lord Chamberlain's Men. ${ }^{11}$ 
Although there are many records of players performing at Newington Butts, we have not been able to solve the identity of the players in the privy council letters of 11 May 1586. In the first of these letters, the councillors wrote to the Surrey justices to order them to offer assistance in policing the recent restraint against 'playes and assemblies of the people at the theatre or anie other places about Newington', 12 and in the second, to the lord mayor of London, they provide assurance that the general order had been enforced by virtue of the first letter, 'prohibiting of the use of playes at the theatre and th'other places about Newington out of his charge.' ${ }^{13}$ Neither letter contains sufficient information from which to even hazard a guess as to the identities of the players who might be performing in Newington in breach of the existing order. For scholars of the early modern playhouses, this gap in our knowledge is particularly frustrating because it leaves too large an interval between what we are now quite confident was happening at Newington Butts until 1580 and the manner in which the venue was used during the last few years of its operational life. Until 1580, Warwick's Players almost certainly used the Playhouse as a long-term regular home base, and so the possibility that Oxford's Players originally used the venue this way in the first instance would make sense. By 1590 or so, at around the time of the watermen's petition and the Rose closure, companies apparently only used the Playhouse as a stop-gap measure when circumstances necessitated, and by then 'of longe tyme plaies haue not there bene vsed on working daies. ${ }^{14}$ Sometime during the intervening decade, the Playhouse fell into relative decline as a regular playing venue, but how much of a 'longe tyme' this was before 1590 is unclear. If we can determine which company was performing there in May 1586, and if this was a short- or long-term arrangement, we might better inform our narrative of the site's performance history.

To begin to answer the question of who performed at Newington Butts in May 1586, then, I begin by ruling out the prospect that Oxford's Players continued to occupy the Playhouse for any length of time after 1580. Warwick's company had of course reconstituted itself by the time that Newington Butts was mentioned in the privy council order of 13 May 1580. One school of thought holds that the newly formed Oxford's Players relocated their business to Shoreditch, since Laurence Dutton and Robert Leveson were imprisoned on 13 April for their part in an affray at the Theatre three days earlier, supposedly indicating their occupation of that venue. Edmund Kerchever Chambers subscribes to this theory in The Elizabethan Stage, ${ }^{15}$ and Gurr echoes this notion in his description of the early playing career of Oxford's Players in The Shakespearian Playing Companies. ${ }^{16}$ If Oxford's company had taken up residence in the Theatre by the time of 
this 'affray', then their relocation to Newington Butts in May 1580 is unlikely, unless they felt the Theatre too visible a venue to continue playing after the brawl of 10 April and the plague closure of 17 April. I am more inclined to suspect that Oxford's Players were stationed throughout this time in Newington and that Dutton and Leveson instigated the fracas at the Theatre in an attempt to diminish the already fragile reputation of their main competitor to the north. More on this momentarily. Oxford's Players are next mentioned in a letter of complaint by the vice-chancellor of Cambridge University on 21 June, so evidently they eventually complied with the closure and took to the road, albeit sans Leveson and Dutton. ${ }^{17}$ Thereafter, the company appears frequently on the road, with a regular touring schedule that indicates a sudden detachment from London. ${ }^{18}$

Performers associated with the earl of Oxford did appear at court in January, March, and December 1584 and January 1585, but none has any obvious connection to the players: those appearing in 1584 were listed in court records as 'the children of Therle of Oxforde'19 and the group appearing in 1585 is listed as 'John Symons and other his fellowes Servantes to Therle of Oxforde', being paid for 'feates of actiuitye and vawting', but not for a play. ${ }^{20}$ The players who enjoyed Oxford's patronage were never included on the schedule of the court revels. If members of Warwick's company switched allegiance to a new patron expecting they would simply inherit the regular revels schedule they had previously enjoyed, they were mistaken. Warwick's Players were included on the revels schedule regularly from February 1575 to January $1580,{ }^{21}$ and the prospect of regular court appearances possibly spurred the development of the Playhouse at Newington Butts. ${ }^{22}$ Even if Oxford's company retained most of the same personnel, they retained none of the privileges that had been extended to them as servants of Ambrose Dudley, earl of Warwick and brother to the earl of Leicester, Robert Dudley. The involvement of some of Oxford's men in the 'affray' likely saw them lose favour with the master of the revels when planning the 1580-81 revels, but the earl's own loss of favour surely played a bigger part in the future fate of his players. As Alan Nelson has shown, the summer of 1580 saw Edward de Vere confined to chambers for public quarrels with Leicester (who enjoyed far more favour with the queen), beginning a period of scandal in Oxford's life that resulted in a steep decline in his position, culminating in imprisonment for one month in 1581 and then banishment from court until June $1583 .^{23}$

Following the events of 1580 , provincial touring records show that the company spent the next few years in the provinces for most of the year, with appearances from February to November in 1581 and at least June to November in 1582. ${ }^{24}$ The later start in 1582 could hint at an attempt to gain a new foothold in London 
or even a return to playing at Newington Butts, but the attempt was short-lived. In 1583, the company took on a far more expansive touring schedule extending into December, ${ }^{25}$ and although the earl's stocks were sufficiently recovered to see his 'children' performing at the revels in January 1584, his players were already on the road and performing in Ipswich by 20 January. ${ }^{26}$ The company maintained another busy touring schedule throughout 1584, notwithstanding the 20 s they were paid in Norwich to not play in the city, ${ }^{27}$ and 1585 , but then they vanish from the provincial records save for just two payments spread across the next two years. ${ }^{28}$ Maliverny Catlyn names the company in a letter on 25 January 1587 to Francis Walsingham as one of the major adult playing companies posting playbills around London for performances every day of the week, including the Sabbath. ${ }^{29}$ Could this mean that the company established themselves once again in or near London by the end of 1586 ? The difficulty in using Catlyn to date the company's presence in London becomes apparent when we note that Leicester's Players were performing in Maidstone by 23 January, ${ }^{30}$ despite being also named in the same letter two days later as one of the companies posting bills in London. Catlyn is thus clearly conflating the activities of a number of companies over a longer period of time into a single complaint. Nevertheless, to imagine that some vestige of the company was back in London by 1586 is not unreasonable, but by this time the reality that their lot did not include any further prospects for appearing at the revels would have been abundantly clear.

While some remnant of Oxford's Players remained active by 1586, clearly this company did not continually or even regularly occupy Newington Butts from 1580 up to that time. The company possibly appeared sporadically in Oxford's livery in the provinces in 1586-87 and posted bills in London by January 1587, meaning they could have been at Newington Butts in May 1586, but we have no reason to assume their presence on the basis of the company's earlier occupation of the Playhouse after their initial formation. We are more certain that Strange's Men were not there in 1586 - the documents relating to the Rose closure are very clear that the company only used the Newington venue as a temporary measure, and as Lawrence Manley and Sally-Beth MacLean demonstrate in their booklength study of this company, the earlier incarnation of Strange's/Derby's Men was all but defunct from 1583 to $1587 .{ }^{31}$ Manley and MacLean credit the formation of the Queen's Men as a major catalyst for this period of decline for Ferdinando Stanley's troupe. If Strange's Men found the loss of leading members too great an obstacle to overcome, Oxford's group apparently responded to the loss of their leading members by embarking on a schedule of provincial touring that ossified into a regular calendar of activity for the next two years. As regular touring was 
their response to the closures and scandal of 1580 , we could perhaps expect that the closures ordered in April 1586 would not have prompted the company to settle into Newington Butts in contravention of the ban. More likely, I suspect, is that they would have set their sights toward East Anglia but failed on this occasion to build a broader itinerary on top of their appearance in Norwich.

The touring records of Oxford's Players are thus helpful in determining that after the 1580 'affray' and the plague closure of that year, the company took more regularly to touring rather than to an extended run at performing in any venue close to London. Provincial touring records from 1586 help us eliminate other companies from being the target of the privy council's interest in performances at Newington in May of that year. Courtesy of city council minutes in Oxford recorded on the same day as the privy council's letters, we know that Essex's Men were given special permission to perform 'onlie at this tyme' in the Guild Hall court in that city. ${ }^{32}$ Since the company was in Oxford, it makes sense to exclude them from the list of candidates at Newington Butts at the same time. While Oxford is close enough to London that the company could have played in Newington several days prior to the privy council issuing its letters, and then set off for Oxford in time to arrive for a performance on 11 May, the particular value of the records is also in helping us to reconstruct likely trajectories. In the case of Essex's Men in 1586, their presence is recorded in April in Bristol ${ }^{33}$ and Ludlow, ${ }^{34}$ suggesting strongly that they were already on tour and arrived in Oxford in May from Shropshire, to the north. In a similar vein, the earl of Sussex's Players can be found in Dover in February, ${ }^{35}$ Southampton in March, ${ }^{36}$ and most importantly in Bath in May, ${ }^{37}$ placing them well clear of London at the time. To eliminate Sussex's Players from a list of potential Newington occupants, we must situate them outside London at this time, since they are one company that might have had genuine cause, unlike Oxford's Players, to think that they might yet be needed at the revels - this company, often performing under the name of the Lord Chamberlain's Men owing to Thomas Radcliffe's tenure in this position, were a regular inclusion in the revels calendar from 1577 to 1583 . Yet following the earl's death in 1583, the company appears to have disbanded for a short time before reforming under the ninth earl of Sussex Henry Radcliffe's patronage and then taking exclusively to touring from 1585 until 1593.38

If maintaining a performance schedule in close proximity to London was important for companies likely to appear at the pleasure of Her Majesty, then the prime candidates in 1586 would have been those also named in Catlyn's letter of January 1587: the queen's own company and the players who wore the liveries of the earl of Leicester and the lord admiral Charles Howard. The Queen's Men 
were the sole men's company at the revels from 1583 to 1585 , and the Admiral's Men joined them in the 1585-86 season. ${ }^{39}$ The record of a court performance on 6 January 1586 also names both the Admiral's Men and the servants of the lord chamberlain. In the revels at the end of the same year, on 27 December, Leicester's Men - who had been frequent performers at the revels from 1572 to 1582 - made a one-off final appearance at court. The Queen's Men were created by royal warrant when, on 10 March 1583, the master of the revels Edmund Tilney was authorized to select the twelve best players from among the leading adult companies to come together in a single company that could be counted on to provide the best entertainment for the queen. ${ }^{40}$ As Scott McMillin and Sally-Beth MacLean explain in The Queen's Men and Their Plays, the company was certainly expected to dominate the court revels schedule but they were also 'formed to travel too, and while it is right to think of them as holding an advantage among adult companies on the court schedule, it is even more important to think of them as holding an advantage across the country'. ${ }^{41}$ After their formation, the company immediately took on a heavy touring schedule, appearing in eighteen provincial records as far afield as Ipswich and Nottingham from April to November 1583, before returning to London in time to appear in the Shrovetide play and begin their exclusive foothold at the revels on 26 December of that year. ${ }^{42}$ Yet we can ask if the plan to be a touring company between revels seasons was ever expected to extend beyond the company's first year of operations - they did not immediately return to touring at the conclusion of their revels commitments on 3 March 1584. Instead, we find them until June 1584 occupying the Theatre in Shoreditch.

We can confidently link the Queen's Men to the Theatre at this time because they are named as the occupants in a letter by the recorder of London, William Fleetwood, to Lord Burghley, explaining a series of events from 10 to 14 June. On the first of these dates, 'one Browne, a serving man in a blue coat' started a fracas at the door of the Theatre and in the ensuing fight struck a number of 'handicraft apprentices' and boys, and with his sword 'wounded and maimed one of the boys upon the left hand'. ${ }^{43}$ In what followed, upwards of a thousand people assembled nearby and chased this Browne through the streets, but he evaded capture. Spurred on by this incident, the mayor on Sunday sent to Whitehall a request 'for the suppressing and pulling down of the Theatre and Curtain', but succeeded in only gaining an order for the first of these punishments, extended nevertheless to an order to suppress all of the playhouses in and around London. ${ }^{44}$ The Queen's Men and earl of Arundel's players are specifically named in relation to the order, indicating that they were the occupants of the Theatre and the Curtain at the 
time - the queen's company must have been at the Theatre because in obeying the order to vacate the venue they advised Fleetwood to also send for 'the owner of the Theatre', James Burbage, who it seems was 'a stubborn fellow' and was refusing to obey. ${ }^{45}$ Importantly, they complied, which can explain their early July appearance soon afterwards in Cambridge, where they were paid 20s to play in the town before the mayor and a further 50 s by the University authorities not to play there. ${ }^{46}$ Another twelve payments are recorded in the provinces through to October, and then the company returned to London for the start of the revels in December $1584 .{ }^{47}$

The biggest test of the idea that the Queen's Men formed with the intention of touring between court commitments comes from their schedule in the following year. McMillin and MacLean gloss the company's itinerary for 1585 with reference to their appearances at Leicester House in London in April and November, the first of which is reportedly undertaken 'before their summer tour', and the second 'before their Christmas court shows'. ${ }^{48}$ No other mention appears in the volume about the company's activities in the provinces in 1585, and a glance at the list of recorded performances reveals only one that can count as evidence of activity outside of London or the court calendar. The Cambridge Town Treasurer's Books for $1584-85$ lists a payment to 'ye Queens players' ${ }^{49}$ with only its relative placement in the ledgers - and the company's earlier visit to the same town already in 1584 - to confirm the likelihood that this payment occurs in 1585 and not late 1584. McMillin and MacLean reckon a date somewhere between February and July. The only other provincial record listed for 1585 is unclear: an undated payment of 30s in the Norwich Dean and Chapter Receivers' Accounts to 'domine Regine quam seruientibus diuersorum Mangnatum vocatis gameplayers' 50 (servants of the queen and various lords, called gameplayers) could include the queen's playing company or it could refer to some other amalgam of 'gameplayers' that included some servants of her majesty. In any case, we may still agree with McMillin and MacLean that these two records relate to dramatic performances by the Queen's Men, yet also conclude that the schedule for 1585 is barely a fraction of the size of the summer tours of 1583 and 1584. Possibly, even three years into their existence, the company was aiming to situate itself more regularly within the vicinity of London, with only occasional jaunts into the countryside.

In 1584, before the Queen's Men departed London for Cambridge, the company put a petition to the privy council to be allowed exclusive freedoms to perform within London, but the council's response was not so generous: the councillors objected to the players' request to perform to 'the basest assemblies in London 
and Middlesex' and observed that since the company's formation, London had become home to numerous companies 'calling themselves the Quenes players'.51 The council agreed, then, that they would 'tolerate' the Queen's Men to perform in London so long as they restricted performances to private houses and did not divide themselves severally at any time. If the council's response did not meet with their approval in 1584, perhaps the company members did instead attempt in 1585 to restrict themselves for the most part to the private playing places around London. In the revels of 1585-86, though, the company was forced to share the court schedule with other companies, so their attempt to secure a London monopoly was already put to an end. In 1586, the Queen's Men returned once more to a full touring schedule, and would continue to do so for every year thereafter until their inevitable demise with Elizabeth's death in 1603.52 Importantly, through April to July, the Queen's Men were found in Bath, Bristol, and Exeter, making any detour back to London to perform at Newington in early May a most unlikely proposition. ${ }^{53}$ While this last set of provincial touring records should be sufficient to eliminate the Queen's own players from our list of candidates, I feel it necessary to cover their movements (or lack thereof) in 1584 and 1585. Their second and third years of existence might, in fact, contradict the sense that they were formed to travel, but they certainly travelled by 1586, after any earlier stratagem designed to gain a monopoly in London had been thwarted.

Prior to their appearance in the revels on 27 December 1585 and 6 January 1586, the Admiral's Men had previously performed at court as Lord Howard's Players from 1576 to $1578,{ }^{54}$ but then disappeared from the public record following a number of performances in 1578 to 1579.55 The appearance of a company performing under the lord admiral's name on three occasions in Kent in 1585 suggests Howard saw his elevation to this position in May of that year ${ }^{56}$ as an opportunity to adopt a new company. While a performance in Folkestone is dated between 8 September 1584 and 8 September 1585, the timing of Howard's appointment indicates a more precise range of May to September $1585 .{ }^{57}$ This timing fits well with the precisely dated appearance in Dover (12 June 1585), ${ }^{58}$ suggesting that the appearances in Kent were all concentrated in a tour of the county, which included the undated appearance in Hythe (between February 1585 and February 1586). ${ }^{59}$ The Dover record is of particular interest because it accounts for a payment made to 'my Lord admiralles and my Lord of Hunsdons players', ${ }^{60}$ pointing to a combined performance with the company of Lord Hunsdon, Henry Carey. The second company does not appear in the accounts of Folkestone or Hythe, but it may be worth considering that the two companies did combine regularly, since Hunsdon's company appears again under Carey's 
new title alongside the admiral's players at court on 6 January and also, before 9 June 1586, in a record of payment in Leicester to 'the Lorde Chamberlens and the Lord Admiralles Playors more then was gathered'. ${ }^{61}$ Elizabeth Tavares has demonstrated that the Admiral's Men routinely engaged in supplemented playing combinations prior to 1594 , so this regular combination with Hunsdon's players in the first year after they were reconstituted likely became the template for their future collaborative playing arrangements. ${ }^{62}$ These observations encourage us to think of the movements of the Admiral's Men and Chamberlain's Men as intertwined in the months surrounding the April 1586 restraint.

Given their combined appearance at court, both companies were in London during the winter of 1585-86. The Admiral's Men appear in Ipswich in February $1586,{ }^{63}$ but to link this appearance to a tour is difficult. They appear in Rye in July, ${ }^{64}$ and the payments recorded in Folkestone (before September 1586) ${ }^{65}$ and Hythe (from February 1586 to February 1587$)^{66}$ could again align in a way that suggests all three were covered in a tour of Kent in the summer of 1586. An undated payment in the November 1586 accounts in Coventry ${ }^{67}$ could cover a performance anytime in the preceding twelve months, but this city would not likely be the only other stop recorded in a northern tour that included Suffolk to the east. The same account also records payments to several other companies, one of which is the Lord Chamberlain's Men, indicating that the two companies were not together by the time each of them made it to Warwickshire. My sense is thus that the two companies frequently combined in performance from around June 1585 but separated following their appearance in Leicester before June 1586. Exactly when they were in Leicester is unclear, so the companies' joint appearance in that city cannot serve as evidence that the companies were elsewhere in May 1586. Nevertheless, it does indicate that the Admiral's-Chamberlain's combination continued beyond their court appearance in January and this indication helps us to locate both, in London, at the Theatre. Since at least 1584, the owner of the Theatre identified as a servant of Carey's. Although Burbage had previously been a leading member of Leicester's Men, his response to the order of June 1584 was to refuse to come to the recorder to hear the order for the closure of the Theatre and Curtain, boasting that he 'was my Lo. of Hunsdons man' and answerable only to his master. ${ }^{68}$ Given Burbage's allegiances, Leicester's Men plausibly enjoyed most frequent use of the Theatre from 1576 to 1583 , another reason to suspect that Oxford's Players were not the occupants at the time of the affray of 1580. Then, when Leicester's Men declined after the formation of the Queen's Men, the new company took up the lease until June 1584, before Hunsdon's players became the venue's principal occupants into 1585 and 1586. If Howard's and 
Hunsdon's men routinely combined for performances at this time, then Burbage could certainly also have accommodated both at his Theatre. While I cannot rule these companies out altogether, I contend that neither would have seen the closures of April 1586 as a reason to vacate one banned venue only to take up a short lease in another site covered by the same order.

Arundel's Players, who had been performing at the Curtain at the time of the closures of June 1584, are also unlikely to have relocated to Newington by 1586 . In July 1584, we find them performing in Ipswich and then Norwich, clearly in compliance with the order to vacate the Curtain, and later in the same year they appeared in Leicester. ${ }^{69} \mathrm{~A}$ record of payment to a company under Arundel's patronage in the Norwich Chamberlain's Accounts for $1585-86,{ }^{70}$ moreover, indicates a performance in that town after September 1585. The earl, however, had since 25 April 1585 been imprisoned as a recusant in the Tower of London. While a Norwich clerk evidently accepted a license from players donning Arundel's livery sometime after September 1585, many others would not likely make the same mistake. Phillip Howard had been disgraced, was attainted in 1589, and spent the remainder of his natural life in the Tower. ${ }^{71}$ The company's tenure at the Curtain suggests that Arundel might have been grooming his players for court duty in 1584, but the cloud over his name and title would put an end to any such aspirations. I am confident they had already disbanded by May 1586 .

A similar fate seems to have befallen the earl of Worcester's Players, who were at the peak of their powers at the start of 1584 but disappear from the records by the end of the year. With major acting talents such as Edward Alleyn, Robert Browne, and James Tunstall among their number, the company must have been the envy of others who were stripped of major talent by the formation of the Queen's Men. In June 1583, the company was paid 26s 8d not to play in Norwich, but it performed in any case, leading the mayor to insist the company's patron be notified of its misconduct - the company's 'submyssion \& earnyst intreaty' caused him to change his mind. ${ }^{72}$ Not having learned their lesson, the company members repeated the offense with additional misbehaviour in Leicester the following year: on 6 March 1584, the company arrived at that town, and one of its members found the licence of the Queen's Men - who appeared just three days earlier - had been left behind in their inn. The company decided to claim that they were in fact the Queen's Men and that the previous company appeared under fraudulent circumstances; the town authorities saw through their scheme and refused them permission to play, to which the company responded by abusing the mayor personally and then marching with 'drum $\&$ Trumppytts thorowe the Towne, in contempt of $\mathrm{Mr}$ Mayor. ${ }^{73}$ Later, however, they appeared again before 
the mayor, begging his pardon and agreeing to issue a public apology if they could be allowed to perform, to which he relented. Perhaps Leicester's mayor extracted more than their apology, since the company appears on only three further occasions in provincial records before the end of the year, and then not at all again until more than five years later, during which time some of their leading players had moved on to the Lord Admiral's Men. I am thus also confident that Worcester's company were not still active in May 1586.

A number of other companies appear in provincial records in 1586 but can be ruled out of contention. The earl of Hertford's company appeared in Faversham and Marlborough after August 1586, but this appearance is the first in connection with his name since $1582,{ }^{74}$ and these would be its last appearances in the public record until 1590. The company's brief clusters of appearances are characteristic of the many minor troupes that litter the provincial record - the players of Henry Cavendish, ${ }^{75}$ Thomas Cecil, ${ }^{76}$ and Lord Mordaunt, ${ }^{77}$ for example, all appear in the provinces during 1586 but in one-off performances in specific locations, indicating that they were created only as occasional troupes. The companies of the Lords Berkeley, Chandos, Morley, Sheffield, and Stafford all had longer careers than these occasional troupes, but none appears to have ever performed in or near to London and their shorter touring schedules and limited geographical range suggests that they were also only occasional performers, albeit on more frequent occasions than those I mentioned above. The companies of the first four appear only once in the provincial records for 1586: Berkeley's Players in Hythe (undated), ${ }^{78}$ Chandos's Players in Dover (13 August), ${ }^{79}$ Morley's Players in Smithills Hall near Bolton (first week of July), ${ }^{80}$ and Sheffield's Men in Coventry (after 26 October, and their last ever appearance in the provincial records). ${ }^{81}$ Stafford's Players appear twice in 1586, but both in Devon: in Barnstaple $^{82}$ and in Exeter. ${ }^{83}$ These two performances in relatively close geographical proximity in an otherwise unproductive year lead me to wonder if these guildhall performances were practice for a more lucrative performance at an estate in the vicinity - Tawstock Manor, home at the time to the earl of Bath, William Bourchier, may fit this bill, being only a few miles from Barnstaple. No doubt a similar estate of some worthy or noble could be identified in close proximity to the sites of other one-off performances. The appearance in Ipswich in February 1586 by the Lord Admiral's Men might even have been a stop on the way to an occasional performance, although the nearest estate of worth that I can identify at the time is Somerleyton Hall, the residence of Sir John Jernegan and his wife Catherine, daughter to George Brooke, Lord Cobham. ${ }^{84}$ For my purposes here, 
the observation suffices that none of the lesser occasional troupes had any occasion to set its sights on Newington Butts during this year.

What, then, of Leicester's Men, the only remaining major adult playing company that was active into 1586 and not yet ruled out by the process of elimination I have been applying here? The company had been gutted by the formation of the Queen's Men in 1583, and Burbage likely cast the company aside at around the same time, as I have noted. While the surviving documentary record for the remainder of 1583 makes no mention of them, in 1585 their presence is recorded again in a number of locations: starting in London (where they performed at Leicester House and the records show that comedian Will Kempe was paid 10s more than the other members), ${ }^{85}$ they went to Norwich (where they were paid not to play), ${ }^{86}$ Sudbury and Ipswich in Suffolk (2 and 4 June), ${ }^{87}$ Leicester (after 10 June), ${ }^{88}$ Bath (in August), ${ }^{89}$ Coventry, ${ }^{90}$ Gloucester, ${ }^{91}$ and Abingdon (after 29 September). ${ }^{92}$ Yet in December 1585, Leicester embarked on an expedition of the Low Countries, taking fifteen players and twelve musicians with him. ${ }^{93}$ These players possibly accompanied Leicester only for the initial stages, as MacLean observes, ${ }^{94}$ returning for a tour that included a performance on 24 March in Exeter. ${ }^{95}$ Gurr claims, instead, that the company might have split into two, with one cohort on overseas duty and the other continuing to perform domestically under the royal patent that his players enjoyed. ${ }^{96}$ He provides no specific evidence in support of the claim, so I wonder if he is simply echoing the proposition put forward by Murray: 'in 1585 the company seems to have split, many of its important actors going abroad', which he bases on the record of 'English players in the yard' at Elsinore in 1585 and his belief these players must be the same as those named a year later on Leicester's campaign. ${ }^{97}$ With Leicester's campaign not beginning until December, no basis exists for connecting the earlier record of unnamed players in Elsinore with those who accompanied Leicester.

As MacLean points out, the dates are sufficiently misaligned and provide no overlap between domestic performances and performances abroad, meaning the players could have returned to England for a short tour and then, by 23 April, accompanied Leicester in Utrecht, where they performed on St George's Day. ${ }^{98}$ Kempe was certainly with him on 6 May for entertainments in Amersford, as MacLean also notes. After their performance in Exeter, the company goes quiet in the provincial records in England until later in the year, so no clash of dates supports the idea of a split company. On 30 May, Leicester's accounts show that Thomas King (listed as one of Leicester's musicians) was given a payment for the purchase of apparel in Arnhem, Germany, and Robert Browne (also listed as a musician, but more probably the same player who had earlier been in Worcester's 
company and would later lead several playing companies on tours in Germany) was paid for his return to England. ${ }^{9}$ Then, on 1 June 1586, a payment of $£ 5$ is made in Arnhem to a group of players to proceed to the court in Elsinore, Denmark. The presence of George Bryan and Thomas Pope (who became members, along with Kempe, of Strange's Men) is recorded there along with King, Robert Percy, and Thomas Stevens from 17 June onwards, and Kempe is recorded as having joined them there by August. ${ }^{100}$ What intrigues me most about this list is that not one of these five players who arrived in Elsinore on 17 June 1586 is mentioned earlier in Leicester's accounts or in the continental records of the initial foray into the Low Countries from December 1585 onwards. Yet only two days prior to their departure, one of their number is given money to buy new apparel - this detail, to me, suggests that these five were only newly arrived in Arnhem in the days before their assignment to proceed to Elsinore. Couple this payment to the payment for one of the players who does appear in earlier records of the campaign - Browne - to return home to England, and I believe we see evidence of a changing of the guard on tour.

Unfortunately, no records have survived in Robert Dudley's own household accounts for the period from 14 April to 26 May. To attempt to make sense of the movements of his players in this interval, then, I propose the following explanation that draws broadly on the documentary record relating to Leicester and his musicians and players during 1585 and the first half of 1586 . Having been gutted by the formation of the Queen's Men, Leicester's Men temporarily folded in 1584 , but in keeping with the earl's visions of a triumphant diplomatic European campaign, they went on tour in 1585 partly to prepare themselves for the rigours of touring abroad. The presence of Browne and Robert Wilson, ${ }^{101}$ among others, also suggests that the company was using this time to recruit talent from the other companies to ensure the earl would not lose supply of top talent for his campaign. The group's performance in Exeter, rather than being one stop among several on a domestic tour, might have been a stopover on route to a performance at Tawstock, not unlike that of an occasional company, but this performance was itself a rehearsal for a performance before nobility on the continental tour to follow. Finally, in April, Leicester determined a need for still more talent as members of his overseas troupe began to beg leave to return home, so the likes of Bryan and Pope were hastily enlisted to restock the company abroad, and they arrived in Arnhem shortly before the end of May, requiring new apparel for the appearance ahead at the court of Elsinore.

Given that no other company neatly fits the bill for playing around London in May 1586, I propose that the explanation offered here for the turnover in the 
names of key personnel on Leicester's continental campaign provides us with solid grounds for suspecting that a makeshift troupe bearing Leicester's imprimatur performed at Newington in late April or early May in an attempt to prepare for the task that lay ahead. When Leicester sent word that he would require more players to despatch to Denmark, the players earmarked for departure could have headed toward London to bunker down at the vacated Playhouse in Newington to ready themselves for the royal performances abroad. This suggestion would not of course be an argument that 'Leicester's Men', as such, played at Newington Butts in May 1586, but then perhaps no single entity constituted such a company at that time. I do not make this claim to signify agreement with the proposal that two discrete troupes existed - one domestic and one international — but, rather, that a serious challenge to our standard understanding of what constitutes an early modern adult playing company confronts us in 1586. At the very least, I hope I have shown that all other companies about which the documentary record has furnished us with a picture of activities in both London and the provinces reveal no other candidate for the concerns that warranted the privy council to take action in Newington Butts on 11 May 1586. I also hope to have demonstrated that no simple division exists between London companies and provincial companies, just as the companies may themselves also bleed one into the other during the 1570s and 1580s. Yet as the documentary record allows us to refer to the playing companies with some kind of certainty — we are dealing with relatively concrete entities operating under the patronage of a specific individual we can use our old friend Occam in relation to the question of May 1586: with sound reason to exclude all other candidates, I merely submit the suggestion that a fragment of Leicester's Men (Bryan, Pope, et al.) performed at Newington Butts in 1586. 


\section{Notes}

1 My thanks to Callan Davies, Andy Kesson, Elizabeth E. Tavares, and the delegates of the Before Shakespeare conference, Roehampton, 2017, for their initial enthusiasm for the ideas presented in this essay. My deepest gratitude to Sally-Beth MacLean for her generous insights and cross-checking of evidence in REED. Naturally, any remaining errors are my own.

2 On the name of the Playhouse, see Laurie Johnson, 'The Two Names of Newington Butts', Shakespeare Quarterly 68.2 (2017), 196-7, https://doi.org/10.1353/ shq.2017.0019.

3 John Tucker Murray, English Dramatic Companies, 1558-1642, 2 vols (London, 1910); Andrew Gurr, The Shakespearian Playing Companies (Oxford, 2003), https:// doi.org/10.1093/acprof:oso/9780198129776.001.0001.

4 William Ingram, The Business of Playing: The Beginnings of the Adult Professional Theater in Elizabethan London (Ithaca and London, 1992), 168-71. For more recent clarification of the likely reasons for establishing a playhouse near London in 1575 , see also Laurie Johnson, Shakespeare's Lost Playhouse: Eleven Days at Newington Butts (New York and London, 2018), 75-7, https://doi.org/10.4324/9781315098012.

5 John Roche Desant (ed.), Acts of the Privy Council of England, vols 1-25 (London, 1890-1901), 1577-78.381. Hereafter by volume and page as APC.

6 Johnson, Shakespeare's Lost Playhouse, 84.

7 Ingram, Business of Playing, 176.

8 APC, 1580-1581.15.

9 Ingram, Business of Playing, 174.

10 Johnson, Shakespeare's Lost Playhouse, 93-6.

11 R.A. Foakes (ed.), Henslowe's Diary, 2nd edn (Cambridge, 2002), 21-2.

12 APC, 1586-1587.99-100.

13 Ibid, 102.

14 Foakes, Henslowe's Diary, 285.

15 Edmund Kerchever Chambers, The Elizabethan Stage, vol. 2 (Oxford, 1923), 100.

16 Gurr, Shakespearian Playing Companies, 307-8.

17 Glynne Wickham, Herbert Berry, and William Ingram (eds), English Professional Theatre, 1530-1660 (Cambridge, 2000), 250-1; Alan H. Nelson (ed.), REED: Cambridge (Toronto, 1989), 1.290-1.

18 The company's itinerary is summarized in Gurr, Shakespearian Playing Companies, 309; see also the thirty-five records of provincial performances on the REED Patrons and Performances site for Oxford's Players at the time of writing. 
19 Chambers, Elizabethan Stage, 4.160; John H. Astington, English Court Theatre, 1558-1642 (Cambridge, 1999), 231.

20 Chambers, Elizabethan Stage, 4.161.

21 Astington, English Court Theatre, 227-30.

22 See Johnson, Shakespeare's Lost Playhouse, 77.

23 Alan H Nelson, Monstrous Adversary: The Life of Edward de Vere, 17th Earl of Oxford (Liverpool, 2003), 200-1; 266-70, https://doi.org/10.1353/shq.2005.0058.

24 R.W. Ingram (ed.), REED: Coventry (Toronto, 1981), 296, 298; James M Gibson (ed.), REED: Kent: Diocese of Canterbury (Toronto, 2002), 2.630; James Stokes with Robert J Alexander (eds), REED: Somerset, Including Bath (Toronto, 1996), 1.13.

25 Gibson, REED: Kent: Diocese of Canterbury, 2.600.

26 Gurr, Shakespearian Playing Companies, 314; Murray, English Dramatic Companies, 1.348 .

27 David Galloway (ed.), REED: Norwich 1540-1642 (Toronto, 1984), 81.

28 An undated record of payment to 'therle of Oxenfordes Players' is in the Norwich accounts for 1585-86, and Gurr records a payment in Ipswich (1586-87). While Gurr also records a payment for York in June 1587, this is a dating error, as the REED records for York show that the payment was made during the company's 1585 tour - Alexandra F. Johnston and Margaret Rogerson (eds), REED: York (Toronto, 1979), 1.419; Galloway, REED: Norwich, 84; Gurr, Shakespearian Playing Companies, 314.

29 Nelson, Monstrous Adversary, 246.

30 Gibson, REED: Kent: Diocese of Canterbury, 2.718.

31 Lawrence Manley and Sally-Beth MacLean, Lord Strange's Men and Their Plays (New Haven, 2014): 19-23, https://doi.org/10.12987/yale/9780300191998.001.0001.

32 John R. Elliott, Jr, and Alan H. Nelson (eds), REED: Oxford (Toronto, 2004), 1.203.

33 Mark C. Pilkinton (ed.), REED: Bristol (Toronto, 1997), 128.

34 Alan B Somerset (ed.), REED: Shropshire (Toronto, 1994), 1.88.

35 Gibson, REED: Kent: Diocese of Canterbury, 2.478.

36 Gurr, Shakespearian Playing Companies, 183; Murray, English Dramatic Companies, 1.307 .

37 Stokes and Alexander, REED: Somerset, 1.13.

38 No fewer than thirty-two records of provincial performance are recorded on the REED Patrons record for Radcliffe during this period.

39 Astington, English Court Theatre, 231-2.

40 Wickham, Berry, and Ingram, English Professional Theatre, 208.

41 Scott McMillin and Sally-Beth MacLean, The Queen's Men and Their Plays (Cambridge, 1998), 5 . 
42 Ibid, 175.

43 Wickham, Berry, and Ingram, English Professional Theatre, 345.

44 Ibid, 346.

45 Ibid.

46 McMillin and MacLean, Queen's Men, 66, 175.

47 Ibid, 175-6.

48 Ibid, 20.

49 Nelson, REED: Cambridge, 1.313.

50 Galloway, REED: Norwich, 82.

51 Chambers, Elizabethan Stage, 4.302.

52 McMillin and MacLean, Queen's Men, 176-88.

53 Ibid, 176; Stokes and Alexander, REED: Somerset, 1.14; Pilkinton, REED: Bristol, 128; John Wasson (ed.), REED: Devon (Toronto, 1986), 163.

54 Astington, English Court Theatre, 228-9.

55 In 1578, the company certainly appeared in Rye on 19 July and Bristol in the first week of September. There is also a record of payment in Bath for a performance between July 1578 and June 1579, and of one in Coventry between November 1578 and October 1579, either or both of which could cover the same tour indicated in the 1578 payments. In any case, the company certainly disappears from the records after October 1579. Pilkinton, REED: Bristol, 116; Ingram, REED: Coventry, 290; Stokes and Alexander, REED: Somerset, 1.12; Cameron Louis (ed.), REED: Sussex (Toronto, 2000), 126.

56 Robert W. Kenny, Elizabeth's Admiral: The Political Career of Charles Howard, Earl of Nottingham, 1536-1624 (New York, 1970), 102.

57 Gibson, REED: Kent: Diocese of Canterbury, 2.581.

58 Ibid, 2.477.

59 Ibid, 2.631.

60 Ibid, 2.477.

61 Gurr, Shakespearian Playing Companies, 302; Murray, English Dramatic Companies, 1.321.

62 Elizabeth E. Tavares, 'Super Troupers; or, Supplemented Playing Before 1594', Shakespeare Studies 45 (2017), 77-86.

63 Gurr, Shakespearian Playing Companies, 254; Murray, English Dramatic Companies, 1.141 .

64 Louis, REED: Sussex, 131.

65 Gibson, REED: Kent: Diocese of Canterbury, 2.582.

66 Ibid, 2.631.

67 Ingram, REED: Coventry, 313. 
68 Wickham, Berry, and Ingram, English Professional Theatre, 346.

69 Galloway, REED: Norwich, 78; Murray, English Dramatic Companies, 1.322.

70 Galloway, REED: Norwich, 84.

71 Henry Fitzalan-Howard (ed.), The Lives of Philip Howard, Earl of Arundel, and of Anne Dacres, His Wife (London, 1857), 56-65; 89-95; 112-21.

72 Galloway, REED: Norwich, 65-6.

73 Murray, English Dramatic Companies, 1.44-5.

74 Gurr, Shakespearian Playing Companies, 314; Murray, English Dramatic Companies, 1.318 .

75 Ingram, REED: Coventry, 313.

76 Galloway, REED: Norwich, 86.

77 Ingram, REED: Coventry, 313.

78 Gibson, REED: Kent: Diocese of Canterbury, 2.632.

79 Ibid, 2.478.

80 David George (ed.), REED: Lancashire (Toronto, 1991), 166.

81 Ingram, REED: Coventry, 313.

82 Wasson, REED: Devon, 46.

83 Ibid, 163.

84 Rev. Alfred Inigo Suckling, The History and Antiquities of the County of Suffolk: With Genealogical and Architectural Notices of Its Several Towns and Villages, vol. 2 (London, 1848), 44.

85 Sally-Beth MacLean, 'The Politics of Patronage: Dramatic Records in Robert Dudley's Household Books', Shakespeare Quarterly 44.2 (1993), 175-82; esp. 180, https:// doi.org/10.2307/2871138.

86 Galloway, REED: Norwich, 80.

87 MacLean, 'Politics of Patronage', 180; Gurr, Shakespearian Playing Companies, 195.

88 Gurr, Shakespearian Playing Companies, 195; Murray, English Dramatic Companies, 1.41 .

89 Stokes and Alexander, REED: Somerset, 1.13.

90 Ingram, REED: Coventry, 310.

91 Audrey Douglas and Peter Greenfield (eds), REED: Cumberland/Westmorland/ Gloucestershire (Toronto, 1986), 309.

92 REED Online: Berkshire, Abingdon, 1585-86.

93 Sally-Beth MacLean, 'Leicester and the Evelyns: New Evidence for the Continental Tour of Leicester's Men', Review of English Studies 39.156 (1988), 487-93; esp. 490, https://doi.org/10.1093/res/xxxix.156.487. For a more recent discussion of this in the context of the longer history of touring by the company, see Sally-Beth MacLean, 'Tracking Leicester's Men: The Patronage of a Performance Troupe', Paul Whitfield 
White and Suzanne R. Westfall (eds), Shakespeare and Theatrical Patronage in Early Modern England (Cambridge, 2002), 246-71.

94 MacLean, 'Leicester and the Evelyns', 490-1.

95 Wasson, REED: Devon, 163.

96 Gurr, Shakespearian Playing Companies, 191.

97 Murray, English Dramatic Companies, 1.34.

98 MacLean, 'Leicester and the Evelyns', 491.

99 Ibid.

100 Ibid, 492.

101 Gurr, Shakespearian Playing Companies, 191. 